\title{
ECLAC, transnational corporations and the quest for a Latin American development strategy
}

\section{Daniel Kerner}

Departments of History

and Economics

University of Illinois

at Urbana-Champaign

kerner@uiuc.edu
This paper analyses the role assigned to foreign direct investment and transnational corporations in the ECLAC development project, examining the history of the institution and its most representative publications. With impressive continuity in its vision and policy recommendations, ECLAC has recognized the need for foreign investment as an aid for Latin American development, but has been cautious about its consequences. ECLAC has continually called for close scrutiny and regulation of the activities of transnational corporations. The main idea underlying these recommendations is that Latin American-owned industries have to be the guiding forces of economic development. In addition, ECLAC has consistently stressed the benefits of Latin American integration in helping expand Latin American industries, foster autochthonous research and development and provide Latin American governments with information and bargaining power vis-à-vis transnational corporations. 
For, essentially, the debate is still defined by two principal questions: one, where lies the responsibility for our lag? In ourselves or in the outside world which exploits us? Two, how can we make progress? By imitating others (the West or Russia) or by fashioning our own way? ALBERT O. HiRsChMAN
I

\section{Introduction}

The economic history of the last 50 years has been one of impressive changes throughout the world. During this period, Latin American countries have embarked on a process of import substitution industrialization (ISI) and have changed their relation to the international economy significantly. ECLAC has played a key role in this process. From its inception, when it provided a concise theoretical framework from which ISI was launched, and down to our own neoliberal times, its analyses and recommendations have always played an important role in Latin American intellectual and political debates.

ISI was intended to reduce Latin America's external vulnerability and to put the region on the path of development. However, the scarcity of investment sources, lack of capital and technological disadvantage were central and pervasive problems. This paper is an attempt to trace how ECLAC addressed these problems and to determine the role foreign capital and transnational corporations (TNCs) were supposed to play in the development strategy it envisaged. It will show the role originally intended for foreign investment as ISI was first proposed. It will deal with the way this vision changed through the years, as the industrialization process advanced and FDI and the participation of TNCs in the region increased and changed. It will also consider how these changes were related to theoretical developments and challenges such as dependency theory and neoliberal ideas. This will be done by reviewing the different stages of ECLAC thinking and interpreting the role played by FDI and TNCs in each of them. It will suggest that, even though significant changes have taken place, and the attention

The author wishes to thank Joseph Love, Guillermo Guajardo, Michael Monteón and two anonymous CEPAL Review referees for their valuable and incisive comments. paid to foreign capital and TNCs has increased through the years, a similar view has persisted: FDI and TNCs are useful or even necessary as a means of gaining access to the capital and technology that can make industrialization possible, since they can function as sources of technological diffusion and economic dynamism. However, a note of caution is always in order: one must be aware of balance-of-payment crises and any increase in foreign dependency. In view of all this, ECLAC has proposed policies of selective engagement and control of TNCs, a transitory role for FDI, and regional integration. Throughout the period, the idea that Latin American-owned industries should be the guiding forces of economic development persists in ECLAC thought.

This paper will trace the views of ECLAC regarding TNCs during each of the five decades of its existence, coinciding broadly with stages in its intellectual development. ${ }^{1}$ The first part analyses the 1950s, when ECLAC thinking was being developed. The concern with foreign capital was present from the outset but increased as the decade advanced, while the emphasis was on attracting public funds. The second part analyses the 1960s, when the need to deal with TNCs became imperative, and when their positive and negative contributions were first evaluated, in the light of a growing recognition that ISI needed to be reformed and transcended. Moreover, the attention paid to TNCs and foreign capital increased throughout the decade. During the 1950s, the emphasis was on the need to attract foreign public-sector capital. By the 1960s, and increasingly thereafter, the need to deal with and attract foreign private-sector investment gained ground. In this stage, TNCs were viewed as a means of fostering exports of manufactured goods (a view that appeared in the

\footnotetext{
${ }^{1}$ The periodization is based on Bielschowsky (1998a, pp. 11-12).
} 
1950s and increased in importance in the following decades), as the limits of ISI were becoming apparent just as the importance of TNCs was increasing worldwide. Next, the paper considers the 1970s, which were marked by the analysis of "development styles". In this third stage, the emphasis was on the limits of what TNCs could contribute, given the region's style of development. Moreover, the analysis of TNCs became a central concern in ECLAC studies. Lastly, it analyses the 1980s and 1990s, marked by the idea of "productive transformation with equity". The attention paid to TNCs and foreign capital is even greater, especially since the 1990s saw a renewal of capital flows to the region and a recognition of the need for more open economies. The need to attract TNCs as sources of technology and capital was highlighted. However, the idea that Latin American firms must guide the development strategy was maintained, and the positive aspects of ISI were recognized. The international economic and intellectual context is considered in every stage.

\section{II}

\section{The 1950s: the early years}

In 1949 (1950 in English), ECLAC published its "manifesto" under the authorship of Raúl Prebisch, setting forth the bases for its understanding of Latin American economic problems (Prebisch, 1950). Its starting point was the particular position as a commodity producer and exporter that Latin America had come to occupy in the international economic system. This was a position that corresponded to the postulates of the theory of comparative advantage. However, according to Prebisch, the economic performance and situation of the periphery contradicted the prediction of the theory of comparative advantage that the increases in productivity occurring in the industrial countries would be transferred evenly throughout the system. On the contrary, Prebisch observed that the region's terms of trade had been deteriorating over the long term. This was caused, in part, by the better organization skills of labour in the centre. In the downswing of the economic cycle, these groups resisted wage cuts. Rural workers in Latin America lacked organization and so were not able to resist downward wage pressures. This meant that the adjustment needed in the centre was transferred to the periphery. The other important factor was the monopolistic power enjoyed by industries in the centre. In later writings, another factor was introduced to account for the deteriorating trend in the terms of trade. This was the inelasticity of demand for commodities at the centre. Known as Engel's law, it stated that as income grew, the share of demand accounted for by commodities tended to decline. In the periphery, by contrast, demand for industrial imports was elastic. This explanation came to be known as the Prebisch-Singer thesis, and became the hallmark of ECLAC.
If industrialization was needed to solve the region's problems, then the structural characteristics of the periphery, the decline in its terms of trade, its low saving rate and the technological disparity with the centre all meant that the process needed to be one of import substitution industrialization. The new industries, therefore, should be encouraged and protected by the State.

Prebisch reflected that the imperative problem posed by the lack of savings for investment meant there was a need for resources other than those of the State. One possibility he envisaged was foreign capital. ${ }^{2}$ While the problem of foreign capital was present from the start, it gained considerably more attention as the 1950s advanced. The first systematic reflection on this aspect appeared in $1954 .{ }^{3}$ Foreign capital "can be seen as a way of securing the additional foreign exchange resources needed to sustain a high rate of development while at the same time eliminating the difference between the demand for imports implied by this and the regular revenues from exports themselves" (ECLAC, 1969 , p. 33). It was also needed as a means of supplementing internal savings.

\footnotetext{
2 Despite the general belief that Prebisch had an anti-export bias, he believed from the start that ISI did not mean "that primary exports should be sacrificed". They provided foreign exchange, and therefore investments to enhance the agricultural exporting sector's productivity were needed (Prebisch, 1950).

${ }^{3}$ Prebisch did however address this issue in The economic development of Latin America and its principal problems: "An immediate increase in productivity per man could be brought about by well-directed foreign investments added to present savings" (Prebisch, 1950).
} 
The low level of foreign capital investment in Latin America in the 1950s was a matter of great concern to ECLAC. ${ }^{4}$ Prebisch explained that foreign investment had played a major role in the previous development strategy, especially the development of infrastructure through FDI and the bond market. However, the bond market had ceased to be accessible to Latin American countries after the defaults of the 1930s. Therefore, given the international situation and the need to lower the cost of investments, he felt that the best solution was foreign aid provided by international financial institutions. These institutions should provide easy access to funds so that Latin American countries could invest in social capital (ECLAC, 1954, p. 15), "at least until the private bond market is reopened" (ibid., p. 15). He proposed a policy of international cooperation whereby industrial countries would provide capital and investments to Latin America, chiefly through these international institutions. This did not need to be a kind of Marshall Plan, because "Latin America's need is for productive loans on very long terms and at rates of interest as low as those permitted by money markets" (ibid., p. 22). He cautioned that this needed to be a temporary form of relief, until the development of Latin American industries allowed them to generate their own resources. The desirability of foreign resources being transitory in character was to remain a central concern of ECLAC. Another important aspect was the need for foreign capital to enter in amounts large enough to produce favourable effects on the region's development. ${ }^{5}$ The goal of this policy was not only to secure investment, but also to raise the saving rate and encourage new investments (ECLAC, 1954). An important proposal was that international funds should be channelled to Latin American businesses through specific State institutions. For example, recognizing the institutional inadequacies of the region, notably its financial institutions, ECLAC proposed the creation of an Inter-American Fund for Industrial, Agricultural and Mining Development. This fund, based on national development plans for each country, would manage the available resources.

The other problem Prebisch admitted was the technological disadvantage faced by Latin American industries and the high cost of keeping up to date and obtaining technology from the centre. TNCs needed to

\footnotetext{
${ }^{4}$ ECLAC estimated that FDI totalled only US\$ 1.6 billion in the first three years of the 1950s (ECLAC, 1954, pp.14-15).

5 This was consistent with the reliance and stress that ECLAC placed on programming. See Hirschman (1961).
}

be involved in some way for Latin America to gain access to the newest technology. This, however, had to be done in a cautious and programmed way. TNCs should not be active across the board; rather, their participation should be guided by the State and confined to determined sectors of the economy, ideally by means of accords between industries for joint participation, technological assistance and personnel training (ECLAC, 1954). This would allow Latin American industries to compete from a better position. Indiscriminate participation would hinder the aim of ISI. As in the case of investments, Prebisch thought there was a need for an international cooperation strategy through which the advanced industrial countries would aid Latin America with specific programmes of technological assistance.

Another related proposal, first raised in 1949, was the creation of a Latin American Common Market (Prebisch, 1950). The logic behind the proposal was that this would give the new industries a larger market and would encourage economies of scale, thereby allowing Latin American industries to compete from a stronger position. The inflow of FDI to the region could be enhanced and controlled, in the way described above, if it took place within the Common Market and was subject to policies coordinated among Latin America's governments. This could be an important way of reducing the region's external vulnerability, if a regional anticyclical policy were applied (ECLAC, 1954).

These ideas, however, were not in accord with the post-war plans of the United States. The security goals envisaged by American policy makers included the integration of the Third World into the world economy, but in a way that would ensure the international economic environment was open to United States trade and investment (Painter, 1999, p. 14). The ECLAC quest for autonomy and control over foreign businesses (which were mainly American in this period) was an evident obstacle to the American project. Moreover, while the United States Government encouraged the integration process in Europe, a Latin American integration project was seen as undesirable. Lastly, Prebisch's idea of economic assistance was not successful, for the United States refused "requests for economic assistance and looked to the military and traditional elites to maintain a favourable climate for foreign investment". American, and therefore international, assistance was directed mainly to Europe and Asia (Painter, 1999, pp. 21-24). For the next 50 years, the resulting tension between the ECLAC project and United States interests would remain a key source of pressure for the acceptance of the ECLAC project. 


\section{III}

\section{ISI transformed: the 1960s}

The early years of ISI produced an ambiguous outcome. On the one hand, nurtured by high protective tariffs and expansionary State policies, industrialization advanced at a rapid pace and the growth rate in the Latin American countries was substantial. ${ }^{6}$ By the 1960s, industry had become the engine of the economy in the largest countries, and was an increasingly important sector across the region. ${ }^{7}$ However, the process soon encountered serious problems. The most evident one was that the import coefficient had risen and shifted towards capital goods (Ffrench-Davis, Muñoz and Palma, 1998, p. 190). As a result, not only did balance-of-payments crises become more frequent, but their impact became even more acute. Even more than in the previous period, economic performance was severely affected by external crises.

The 1960s also saw the birth and development of dependency theory. This was the result of several influences, but the problems of ISI referred to above and disenchantment with industrialization as a means of reducing external vulnerability were factors of the utmost importance. ${ }^{8}$ In contrast with what Prebisch and the early ECLAC writings had claimed, dependency thinkers explained the underdevelopment of the periphery not as a product of a particular development strategy, but as a result of the development of the system. The Cuban revolution implied that a more radical approach than that of ECLAC was gaining ground in the understanding of Latin American problems and solutions.

However, the early 1960s witnessed a positive international climate for ECLAC ideas, as the Kennedy administration, concerned by the Cuban example, changed its international security policies and turned its attention in a more positive way towards Latin America. Influenced by modernization theory, its idea

\footnotetext{
${ }^{6}$ For an overview of the period and the economic performance of the region, see Ffrench-Davis, Muñoz and Palma (1998, p. 187). In the 1950s, Latin America's GDP grew at a rate of $5.1 \%$.

${ }^{7}$ By 1960 its share of GDP was $21 \%$ in the region as a whole, being higher in the largest countries (Ffrench-Davis, Muñoz and Palma, 1998, p. 187).

${ }^{8}$ The origins of dependency theory are of course far more complex, and the wide array of schools of dependency thinking makes them even more difficult to determine. See Love (1996a, pp. 182-201).
}

was that the "Communist threat" should be controlled through the economic development of the Third World. To this end, it launched the Alliance for Progress in March 1961. US\$ 20 billion in foreign aid was to be channelled to the region under this programme over a 10-year period, with the United States Government providing a large part. Of special importance was that the ideas of planning and structural reform achieved further legitimacy, as these were the aims of the Alliance for Progress (Montecinos, 1997). Moreover, the Alliance was in accord with Prebisch's original idea about the type of foreign investment needed in Latin America. However, by the middle of the decade the results of foreign aid were far from significant, especially regarding structural reforms. The discouraging results of Vietnam, increased instability in the Third World and political turmoil at home led United States foreign policy to turn away from aid and the encouragement of economic development and to focus on security instead, the result being support and encouragement for military coups across the region (Painter, 1999, pp. 63-64).

In the light of the real problems encountered by ISI and the macroeconomic instability that ensued, and in an intellectual climate marked by dependency theory, ECLAC needed to revise its analysis and policy recommendations. ${ }^{9}$ It entered this new stage in its intellectual history with renewed analysis and proposals. Contrary to what their critics have stated, Prebisch and ECLAC reacted quickly to this new situation. ${ }^{10}$ In Towards a dynamic development policy for Latin America, Prebisch recognized and emphasized the lack of dynamism of ISI. He found two main problems: external and internal constraints (Prebisch, 1963, p. 15).

Given the external imbalances ISI had brought about, Prebisch called for a deeper industrialization

\footnotetext{
${ }^{9}$ ECLAC never really endorsed dependency theory, but some of its proponents worked in ECLAC. Furthermore, dependency theory evolved from structuralist ideas, and even Prebisch helped develop it and echoed it (Love, 1996b).

${ }^{10}$ For example, Harberger states that "good economics" faced the bulwark of doctrinaire isolationism and protectionism: "the old ECLAC, which actively sponsored and fostered the interventionist, statist, and illiberal policies of the era" (Harberger, 1996, p. 306).
} 
process with a shift towards capital and intermediate goods, which would ease balance-of-payments constraints. External constraints had been created not only by the rise in imports, but also by the lack of export dynamism. Together with this problem, Prebisch perceived a continuing decline in the periphery's terms of trade. For this reason, he claimed that there was an urgent need to act on two fronts, increasing manufactured exports to several markets (including those of the centre) without neglecting traditional exports, whilst taking steps to shore up the terms of trade (Prebisch, 1963, p. 102). Also important as a way of promoting exports was the integration of the Latin American countries into a Common Market (FfrenchDavis, Muñoz and Palma, 1998).

ECLAC was now also emphasizing the importance of the region's social problems. ${ }^{11}$ "The social structure prevalent in Latin America constitutes a serious obstacle to technical progress and, consequently, to economic and social development" (Prebisch, 1963, p. 4). It was "no longer feasible to maintain consumption patterns that imply the dissipation of a substantial capital formation potential" (ibid., p. 13). Structural reforms (such as agrarian reform) were now considered essential. "Latin America must quicken its rate of economic development and redistribute income in favour of the broad masses of the population" (ibid., p. 10).

ISI had aggravated the external constraints, and the problems of capital and investment continued. Furthermore, the nature of the industries developing in Latin America meant that the region still faced a significant technological disadvantage. At least in the largest and most advanced countries, ISI had reached a dead end (Prebisch, 1963). A policy was needed to restrict the consumption of the higher-income groups and encourage exports. However, there was still a need for foreign capital, investment and technology if the ECLAC strategy was to be effective. "We need the outside world to help us to cultivate our own ability, so that the population as a whole can be brought to share in the process of development" (Prebisch, 1963, p. 54). As before, foreign investment was needed on a temporary basis until the region could generate its own resources and technology.

\footnotetext{
${ }^{11}$ This coincided with a change in the perception of development in economic theory, away from an approach that equated development with GDP growth and towards one in which social aspects were part of the definition of development. See Arndt (1987, chapter 4).
}

The role of FDI and TNCs was therefore reinterpreted in this new stage. This review was influenced not only by the general developments already mentioned, but also by disenchantment with the previous strategy. Prebisch had set store by international public aid and financial institutions, but this had not solved the problems. In the 1950s, FDI had accounted for $60 \%$ of all capital movements. By the early 1960s, however, in the spirit of the Alliance for Progress, the focus had shifted to official lending, again in accord with Prebisch's ideas (Ffrench-Davis, Muñoz and Palma, 1998).

In the 1960s the emphasis, where foreign capital was concerned, shifted towards FDI and TNCs. Prebisch now claimed that in this new era a "clear distinction must be made between two types of foreign capital: the out-dated type, with the enclaves which still subsist, and the new type which takes a determined share in the intensive process of industrialization" (Prebisch, 1963, p. 54). "The foreign enterprise must be a nucleus for the dissemination of technology" (ibid., p. 54). But even if the participation of TNCs and FDI was seen in a more positive light, concerns about their presence and suspicions as to the real gains it might bring were still expressed. One problem was the enormous profits some companies made. "The profit incentive is clearly essential if foreign private enterprise is to be attracted. However, it should be the consequence of the advanced techniques such firms bring into the country, the new patterns of production, organization and marketing they introduce into the local milieu." (ibid., p. 55). This was not what usually happened in practice, however, owing to excessive protection and inflation. TNCs could play a role, provided this was firmly regulated and guided as part of a clear development programme. This meant a strong governmental stance to define the place TNCs could occupy. Prebisch thought TNCs could play an important part in a "programme designed to encourage exports", as they brought "knowledge of export practices and external markets" in which Latin American industries were at a disadvantage (ibid., p. 56). ECLAC had recognized the need to encourage exports since the 1950s, and in the 1960s this idea would become a central tenet of its proposals (Bielschowsky, 1998a, pp. 22-23). Prebisch now thought that TNCs could be of help in this endeavour. Again, a "partnership between foreign and Latin American enterprise might be a very suitable solution, from the standpoint both of dissemination of techniques and of improved relations with domestic interests" (Prebisch, 1963, p. 56). In short, underlying all these proposals was the need for 
definite, clear policies such as tax exemptions. "Otherwise, foreign investment might carry undue weight in some branches of economic activity, which would be undesirable from various points of view" (ibid., p. 56). Given the cautious stance towards TNCs, the solutions to this dilemma that Prebisch envisaged were, on the one hand, to progress with regional integration. This would give rise to more efficient industrialization in the region, again because of specialization, complementarity, larger markets and economies of scale. This being the case, Latin American industry could "stand up to foreign enterprise, either by making common cause with it or by competing on an equal footing" (ibid., p. 99). Again, the integration process could also foster autochthonous research and development (R\&D), as there would be more incentives for industries, and this would facilitate policy coordination among Latin American States to encourage R\&D. A complementary part of the strategy was that States should take definite action to promote research that could yield more appropriate and efficient technology.

Alongside State regulation of TNCs, another important idea that appeared in this period -one that should be related to Prebisch's unceasing quest for an international cooperation programme- was the proposal for an international code of conduct to regulate the operations of TNCs. This could be seen as a response to the obvious fact that TNCs were increasing their operations in the region. It is important to note that this was also raised by Prebisch as an important concern at the United Nations Conference on Trade and Development (UNCTAD). ${ }^{12}$

As mentioned, dependency ideas appeared and developed, in part, at ECLAC during the 1960s. The younger generation working under the dependency paradigm also reflected on the role of foreign capital and TNCs. Prominent among these economists was the

12 Prebisch left ECLAC and was appointed Director of UNCTAD in 1964. He left that post in 1969, disappointed by the lack of support and what he considered the organization's lack of achievement. See Dosman and Pollock (1998, pp. 573-603).
Chilean Osvaldo Sunkel. For Sunkel, "it could be argued that until the mid-1950s, what prevailed were forms and methods of incorporating external financial, human, technological and material resources that contributed to the development of an essentially national industry in Latin America. From then on, however, with the decades of crisis and the Second World War now left behind, and coinciding with the rapid expansion of transnational conglomerates and a new stage in the import substitution process in Latin America, the phase of denationalization and dispersion of Latin American industry began" (Sunkel, 1998, p. 513). The latter development, Sunkel thought, was one of the most important factors behind the disappointing results that the industrialization process had yielded (ibid., p. 513). Furthermore, Sunkel thought that the world was probably "moving towards a new variant of the centreperiphery model, from which we thought that import substitution industrialization was liberating us". In this new model, "the international division of labour was taking on a new form, as were its agents: the transnational manufacturing oligopolies" (ibid., p. 515). This model had important consequences, especially the persistence and deepening of the mono-exporting model, the fact that the economy's dynamic influence came from abroad, and the location of basic decisionmaking centres abroad. Sunkel also thought that that the growing presence of TNCs would increase the problem of external indebtedness. Lastly, Sunkel warned that the process of Latin American integration could ruin Latin American industries once and for all by favouring firms from outside the region. This could happen if conditions were created in which "domestic companies are not only disadvantaged, but debarred from obtaining protection from the national State" (ibid., p. 516). Summing up, he said that "the main characteristic of the current system of international economic relations, and probably of the future system as well, is the penetration of the economies of underdeveloped countries by the most powerful agents of developed country economies [TNCs], and especially by those of the American economy, the predominant centre of the capitalist system today" (ibid., p. 66). 


\section{IV}

\section{The landslide and "styles of development": the 1970s}

Since the mid-1950s, governments throughout the region had striven unreservedly to attract FDI and TNCs. This period saw a significant increase in the inflow of FDI to Latin America, attracted by high rates of protection. New TNCs entered the region to occupy leading positions in the production of manufactured and intermediate goods. This outcome was a disappointment, however, for "capital was often raised locally, many investments represented the purchase of an existing firm and there was no guarantee that the seller would reinvest the proceeds locally" (BulmerThomas, 1994, p. 359). This phenomenon only increased during the 1960s, as international trade and notably trade in manufactures continued to grow spectacularly. ISI had now advanced to a further stage in the larger countries, but the problems only became starker. Political and economic instability, rising inflation and more acute external imbalances became common phenomena in the region's countries. These economic and political developments, and the pervasiveness of dependency theory, had the effect of spreading a negative view of ISI. The role that FDI and TNCs had come to play in Latin America only reinforced the suspicions of dependency theorists, who were rising to prominence in intellectual circles in both Latin America and the developed world. ${ }^{13}$

When the 1970s began, the Latin American countries faced even more constant external concerns and instability. The 1973 oil shock put an end to the "golden age" and initiated a period of international financial instability and reduced growth in the industrial countries, coupled with rising inflation. The effects of this crisis put enormous pressures on the development strategy followed by Latin America, especially for oil

${ }^{13}$ It has to be noted, however, that one of the most prominent of them, Fernando Henrique Cardoso, did not have such a negative view of TNCs. This could be seen even in Dependency and development, but appeared much more clearly after he coined the notion of "associated-dependent" development. Cardoso maintained that to view TNCs as opposed to growth and development was wrong. For him, TNCs needed a dynamic market to work and so could actually foster both growth and development. Given the characteristics of the international system and the periphery, attracting TNCs was a feasible way for peripheral countries to attain their potential rate of development (Cardoso, 1973, pp. 142-176). importing countries. This period also witnessed a rise in the standing of monetarist schools that attacked the ISI strategy ferociously.

In spite of all the problems, the enormous financial flows available in the international market allowed Latin American countries to continue without serious reforms, by following a debt-led strategy. This situation meant that these countries' foreign debts were to grow significantly throughout the decade. Nevertheless, several governments across the region were trying to encourage industrial exports. In fact, manufactured exports continued to grow throughout this period, although never to the level necessary to relieve the shortage of foreign currency (Ffrench-Davis, Muñoz and Palma, 1998).

In this situation ECLAC entered its third stage, characterized by the idea of "development styles" (Bielschowsky, 1998b, p. 34). The idea was that the problem of Latin America lay in the style of development being followed. It was basically claimed that the essential issue lay in the social and political structure and in the relationships of power and inequality that sprang from it. ${ }^{14}$ It was the distribution of power and income that determined the outcome of the development strategy. Therefore, for an industrialization process to be successful, the main problem to be tackled was income distribution. This was not a new idea, but it acquired more analytical importance and was recast in a broader framework. The same could be said of the need for manufactured exports, an idea that gained importance at this time.

The economic importance of TNCs was such that ECLAC recognized that "there could be no doubt that the future of the region must perforce envisage various degrees and forms of coexistence with this type of economic unit" (ECLAC, 1981). The attention paid to TNCs in ECLAC studies grew significantly, and they became a central focus of concern rather than an aspect of broader analyses.

Aníbal Pinto, analysing the internationalization of the post-war economy, acknowledged that TNCs had come to play the leading role in the most dynamic

14 The main expression for these ideas is found in Pinto (1976, pp. 99-130). 
sectors of Latin American economies, especially the largest ones (Pinto, 1980, p. 42). By the late 1960s, TNC penetration in manufacturing was particularly marked, with foreign firms accounting for between $30 \%$ and $40 \%$ of total output in the largest countries (BulmerThomas, 1994, p. 315).

TNCs had come into Latin America and adapted to the region's particular "style of development", marked by its unequal income distribution. There was a "contradiction between the transnational objectives of these enterprises and the national objectives aimed at securing an integrative and autonomous style of development... At the internal level, it is expressed in particular through the orientation of the structure of production, which is adapted to the restrictive and elitist demand of the strata with the highest income, while at the external level it is reflected in the incapacity of the transnational corporations to solve the problems of the external bottleneck, which they may even help to make worse, and in their real and potential role with regard to the regional integration processes" (Marinho, 1981, p. 9). ${ }^{15} \mathrm{FDI}$ and a major presence for TNCs were now recognized as inevitable, but they could only have a positive impact (in the original sense of being transitory and regulated and occupying a limited, albeit key, position) if the social structure and the style of development were changed. The emphasis on manufactured exports and the continuing promotion of regional integration were of a piece with the original ECLAC idea that if development was to come, Latin American industries, within a reformed social structure, had to be the guiding force. Aníbal Pinto, however, recognized that the participation of TNCs was problematic, but that with appropriate regulation and pressure they could be directed towards exporting activities, and so it did not appear advisable to "reject outright or excessively curtail the hypothesis of a larger contribution by foreign consortia to industrial-export diversification". It would largely depend on how national policies were put into practice (Pinto, 1980, p. 140).

These proposals were part of what came to be known as the "new international economic order" (NIEO). Strongly associated with UNCTAD, and arguably a logical result of Prebisch's ideas, this became the new framework within which the region was expected to act. At the third regional appraisal in Guatemala in 1977, the idea of a new international development strategy

\footnotetext{
${ }^{15}$ Marinho was a staff member of the ECLAC/UNCTAD Joint Unit on
} Transnational Corporations. within the NIEO came to the fore. It was recommended that "strong encouragement should be given to the work aimed at preparing the international code of conduct governing the activities of transnational corporations" (ECLAC, 1977). Furthermore, governments were now in a better position to negotiate with and control TNCs, since their experience gave them more bargaining power. Not only this, but Latin American countries should share information to increase their collective bargaining power vis-à-vis TNCs. They should also develop measures to promote the restructuring of world industrial production, in particular by securing greater access for manufactured products from developing countries through the reduction of trade restrictions and regulation of TNCs. Easier access to technology should also be guaranteed to developing economies. But as always, it was Latin American industries and technologies that had to be developed. There was an imperative need to create or strengthen institutions in the region that could engage in $R \& D$ or facilitate its transfer.

As the decade advanced, the ideas of ECLAC were faced with their strongest challenges ever. In a politically polarized climate, its reformist stance was losing appeal. ${ }^{16}$ The United States Government had changed its attitude and was supporting and encouraging military interventions to counter the Communist threat. Guerrilla movements throughout the region, a socialist government in Chile and the organized NIEO movement had further polarized the international political environment.

This situation led to further radicalization of dependency theory, and gave it a wider appeal. In the developed world, orthodox monetarist economic ideas were gaining ground in academic circles and, towards the end of the decade, in political ones too. A campaign against the "bad economists", those associated with ECLAC, had begun in United States academic circles in the 1950s. As the structuralist school was branded unprofessional, a professional project was launched to promote "correct" (i.e., monetarist) economics in Latin America. ${ }^{17}$ ECLAC thus became trapped between the more radical critics (followers of dependency theory)

\footnotetext{
${ }^{16}$ ECLAC reformism had its limits since it was an international agency and, at a theoretical level, always assumed the State to be an exogenous factor (Love, 1996b, p. 242).

17 This was done by funding and creating new institutions and by attracting Latin Americans to graduate schools in the United States. The most exemplary case was the accord between the University of Chicago and the Pontificia Universidad Católica in Chile. See Montecinos (1997, pp. 291-295).
} 
and conservative monetarists. Meanwhile, in the Southern Cone brutal military dictatorships were applying monetarist programmes and making the first efforts to abandon the industry-led strategy. The case of Chile is significant: not only had ECLAC ideas played an important role in reformist policy-making in Chile during the 1960s, but its headquarters were located in that country. These attacks on ECLAC structuralism, like the military coups in the Southern Cone, could be related to the clash between the autonomous, regulatory stance of ECLAC and United States business and security interests. The failure of the Alliance for Progress had given rise to a change in United States foreign policy that was increasingly favourable to military interventions and distrustful of what United States officials saw as subversive ideas. Lastly, the state of crisis in the United States economy and the competition it now faced from Japan and Europe implied that any attempt to curtail American business interests especially in the region, where they were hegemonicneeded to be a matter of concern.

The 1970s were also a high point for foreign investment, although it came mainly in the form of financial flows and external debt. The "debt-led growth" strategy would come to an abrupt end in 1982. The region now faced the need to adjust its economies while at the same time dealing with their debt problems in an extremely unfavourable external environment.

\section{$\mathrm{V}$}

\section{From debt adjustment to "productive transformation": the beleaguered 1980s and 1990s}

The besieged position of ECLAC meant that the emphasis on development and production shifted towards a position of opposition to the type of adjustment demanded by the lending banks and IMF (Bielschowsky, 1998b, p. 37). The fourth stage in ECLAC thought was driven by the objective of finding a way out for the region as it faced inevitable adjustment. The main proposal was for "expansionary adjustment". This required an agreement between lenders and Latin American countries as well as a less strict use of fiscal and monetary policies. ECLAC saw this as the only way in which adjustment could be carried out without further damaging the social conditions of the region.

The mid-1980s saw the appearance of new theoretical reflections that transcended the adjustment problems. This is the stage that still permeates ECLAC thinking. Primarily in the works of Fernando Fajnzylber, the main concern was to re-evaluate the ISI experience and to reflect on the feasibility of an industrializing strategy (Fajnzylber, 1990). Central to this reappraisal was the success story of the newly industrializing countries in East Asia. In this light, ECLAC tried to confront the problems of the past and find a way of remedying them. The ISI strategy had not managed to solve the problems of social inequality, mainly because of its lack of technological absorption. The Asian example allowed ECLAC to maintain its stress both on industrialization and on State intervention. ${ }^{18}$ These ideas would crystallize in the proposal for "productive transformation with equity" that was to mark ECLAC analyses through the 1990s (ECLAC, 1990). What was needed now was a "new industrialization" that would put emphasis on the need for "technological progress". In the 1990s, the need for a competitive external strategy complemented these early ideas, with industrialization being seen as the core of productive transformation. As part of this new strategy, Latin America should also address the problems of poverty and inequality through definite measures of income redistribution (ECLAC, 1990).

The position of ECLAC in the 1990s was a feeble one, given the dominance of the Washington Consensus ideas. These ideas had gained importance through the agency of IMF and the World Bank during the 1980s, as these institutions played the leading roles in the debt negotiation process of the 1980s and the structural reform processes of the 1990s. Furthermore, the attempts to debunk structuralist ideas (launched, as we have seen, in the 1950s) had finally been successful, as the economists trained under these programmes came

\footnotetext{
${ }^{18}$ It is interesting that the World Bank and IMF have interpreted the Asian experience in a different light and have used it to justify their free market proposals. See World Bank (1993).
} 
to occupy the highest positions in Latin American governments. The end of the Cold War (1989-1991), with the United States predominant, only gave further strength and support to these new ideas. Moreover, this dominance meant that the proposals of ECLAC had lost such little leverage as they enjoyed. ${ }^{19}$ In this climate, ECLAC had to respond and adapt its ideas.

An important element in this new period, and in the way ECLAC confronted the demanding and hostile intellectual and political climate, was the organization's assessment of the actual achievements of ISI. While recognizing the problems, shortcomings and abuses associated with it, and particularly the negative aspects of State intervention and its lack of emphasis on market forces, ECLAC took a positive view of these achievements. This was essential, given that neoliberal thought blamed ISI for the apparent economic failure of the region, ${ }^{20}$ claiming that it had resulted in the emergence of inefficient industries which had hindered Latin American economic performance. In response, the proposal of the Washington Consensus was to let free markets and an open economy restore efficiency. Any encouragement of industries was seen as "populist" and thus negative (Dornbusch and Edwards, 1991).

In the view of ECLAC, not only had Latin America seen high rates of growth during the "golden age" (1950-1973), but ISI had been more positive than was previously thought in terms of technological learning and development. This provided a strong base from which the region could engage in a transformation towards a more dynamic, competitive and outwardlooking industrial sector (Katz, 1998, pp. 63-75).

The 1990s also marked the return of Latin American countries to the international financial markets after the debt crisis. The 1980s had seen a decline in flows to the region and in the percentage of total international flows it received. ${ }^{21}$ Furthermore, the 1990 s were a decade in which the international economic situation was characterized by increasing flows of FDI, with what were now called the "emerging economies" playing an important role. ${ }^{22}$ The

${ }^{19}$ The current proposal for a free trade area of the Americas, led by the United States Government, is a clear example of this.

${ }^{20}$ For example, Arnold Harberger thinks that the situation in Latin America improved once "good economics" (that taught at the University of Chicago) replaced the "bad economics" of ECLAC. See Harberger (1996, p. 303).

${ }^{21} 1991$ was the first year since the debt crisis in which the region saw a positive transfer of resources (ECLAC, 1995, p. 26).

22 In 1998, these flows reached US\$ 650 billion. Still, the bulk of capital flows went to developed economies. In 1997 the proportion was $59 \%$, and in 1998 it was $71 \%$ of the total. See ECLAC (2000). privatization process in Latin America exerted a great attraction on these flows. The dominant neoliberal consensus regards FDI and TNCs as desirable elements of a good economic situation. In an open, globalized economy, governments should facilitate them and create positive conditions to attract them. Policies that either hinder this or seek to encourage national industries are regarded as counterproductive and unsound by the Washington Consensus.

By contrast with the commercial bank loans which predominated in the late 1970s, foreign investment in the 1990s went mainly into services and productive investments (ECLAC, 2000). These changes prompted a renewed interest in TNCs in ECLAC studies. An important finding was the way these companies' participation in the Latin American economies had changed over recent decades (Stumpo, 1998). Whereas during the ISI years TNCs had tended to invest in intermediate and consumption goods, since the mid 1970s and early 1980s, when Latin American governments were seeking to transform ISI strategy, the bulk of FDI has gone into commodity manufacturing for export. This finding gives support to the original ECLAC claim that TNCs cannot be the guiding forces of development. Important though they might be, the need for technologically advanced industries can only be met from within Latin America itself.

By recognizing the benefits of ISI, by taking the example of East Asia and by showing the shortcomings of what TNCs have to offer the region, ECLAC -in contrast to the Washington Consensus- still promotes positive policies that can help Latin American industries, while recognizing the need for more open economies and freer markets. The imperative is to foster the absorption of the latest technology by Latin American industries so that they can compete internationally. Even if TNCs can help foster exports in certain periods and in certain sectors, the soundness of the region's position in international markets will "depend on the existence and progress of national firms capable of competing -either on their own or with the aid of inputs of foreign capital- against the firms supplying the international market" (ECLAC, 1990, p. 75). Productive transformation with equity has to take place in a context of higher international competitiveness, grounded in a "deliberate and systematic absorption of technical progress". This implies that "proper account must be taken of the need for learning and dissemination of internationally available know-how" (ibid., p. 14). Both technological and human capital advances have to be absorbed so

ECLAC, TRANSNATIONAL CORPORATIONS AND THE QUEST FOR A LATIN AMERICAN DEVELOPMENT STRATEGY • DANIEL KERNER 
that productivity, competitiveness and equity can be improved. According to ECLAC, this has been a neglected aspect in Latin America.

Studies that analyse TNCs and the flows of FDI to the region in the 1990s help ECLAC to hold out against the refusal of support for Latin American industries suggested by the Washington Consensus. As in its early stages, it expects TNCs and FDI to have positive effects, and there is a clear awareness of the need to encourage and attract foreign capital and technology. ECLAC believes, however, that these will never be a substitute for actual Latin American industries, if the region is to develop and tackle its social problems. Another important element in the ECLAC view is its stress on the example provided by Latin American TNCs that have managed to grow and expand successfully, which are thought to be possible sources of economic dynamism (Chudnovsky, 1999). This allows another old idea to

\section{VI}

\section{Conclusions}

As the example of the 1990s shows, ECLAC has continued with its quest to promote a development strategy based on modern industry and technology that will allow Latin America to follow an autonomous path towards development and equity. Throughout the 50year period we have considered, the Latin American and world economies have both changed significantly. In each period, Latin America's relationship with the international economy and with foreign investment has changed its form. The last decade has also been one in which ideological trends are far from coinciding with ECLAC ideas. Globalization, FDI and the participation of TNCs are currently seen as the desired means of development for "emerging countries". ${ }^{24}$ Nevertheless, ECLAC continues its effort to understand these changes within the same framework and under the same

\footnotetext{
${ }^{23}$ In the years leading up to the 1980 s debt crisis, intraregional exports doubled as a share of the Latin American industry total. The main drawback, particularly in the small and medium-sized countries, was that they were unable to provide ISI with the "critical mass" in terms of market size and the degree of competitiveness required for success in the long run (Ffrench-Davis, Muñoz and Palma, 1998, p. 213).

${ }^{24}$ Except of course by the "globalophobics", as Mexico's former president Ernesto Zedillo so strangely termed those who demonstrate at every meeting of international leaders.
}

be maintained: the importance and desirability of regional integration. Although progress has been weak, regional integration has helped to promote trade in manufactured products across the region..$^{23}$

Lastly, the impressive flows of FDI to the region since the 1990s have made it a matter of renewed importance for some sort of regulation to be in place. State regulation is obviously recognized as necessary, but it is weakened by the lack of adequate information. Reviving its old argument about the importance of governments having adequate information and experience to give them bargaining power vis-à-vis TNCs, ECLAC is pursuing studies that should help Latin American governments to regulate TNCs and FDI. In 1999, for example, two shortcomings were recognized: lack of statistical evidence, and regulatory challenges, given the number of channels and agreements through which FDI is directed (ECLAC, 2000). assumptions it originally used. By doing this, it strives to preserve its own idea of what a Latin American development strategy should be. These assumptions and their framework shape its understanding of the nature of foreign investment.

This paper has shown that the position taken by ECLAC towards TNCs and FDI has been a coherent and consistent one through its five decades of existence. This position implies recognition of the need for foreign investment, but has been marked by awareness of the dangers and drawbacks of an uncritical reliance on outside capital. It has also shown that, its continuity notwithstanding, the analysis of ECLAC has adapted and responded to changing economic and ideological conditions, but without compromising its basic position.

The issues of FDI and TNCs are complicated and crucial ones in Latin America, and the likelihood that interdependence will increase and international trade continue to grow tends to render them even more important. In an age when the theoretical consensus tends to disregard the problematic nature of FDI and adopt an attitude of blind faith towards open markets, and when the problems and vulnerability of the region seem to be increasing, the critical effort of ECLAC, if understood in its own framework, is an important voice striving to address and elucidate them. 


\section{Bibliography}

Arndt, H.W. (1987): Economic development. The history of an idea, Chicago, Illinois, Chicago University Press.

Bielschowsky, R. (1998a): Cincuenta años del pensamiento de la CEPAL: una reseña, Cincuenta años de pensamiento en la CEPAL. Textos seleccionados, vol. 1, Santiago, Chile, ECLaC.

(1998b): Evolución de las ideas de la CEPAL, Revista de la CEPAL, número extraordinario, LC/G.2037-P, Santiago, Chile, October.

Bulmer-Thomas, V. (1994): The economic history of Latin America since independence, New York, Cambridge University Press.

Cardoso, F.H. (1973): Associated-dependent development: Theoretical and practical implications, in A. Stepan (comp.), Authoritarian Brazil: Origins, policies, and future, New Haven, Yale University Press.

Chudnovsky, D. (comp.) (1999): Las multinacionales latinoamericanas. Sus estrategias en un mundo globalizado, Buenos Aires, Fondo de Cultura Económica.

Dornbusch, R. and S. Edwards (1991): The macroeconomics of populism in Latin America, Chicago, Chicago University Press.

Dosman, E.J. and D.H. Pollock (1998): Hasta la UNCTAD y de regreso: divulgando el evangelio, 1964-1968, Estudios sociológicos del Colegio de México, vol. 16, No. 48, September-December.

ECLAC (Economic Commission for Latin America and the Caribbean) (1954): International co-operation in a Latin American development policy, E/CN.12/359, New York. United Nations publication, Sales No.: 54.II.G.2.

(1969): El pensamiento de la CEPAL, Santiago, Chile, Editorial Universitaria.

(1977): International development strategy and establishment of a new international economic order: Third regional appraisal, 1977, Cuadernos de la CEPAL series, No. 17, Santiago, Chile.

(1979): América Latina en el umbral de los años 80, E/CEPAL/G.1106, Santiago, Chile.

(1981): Note by the Director, CEPAL Review, No. 14, E/CEPAL/G.1179, Santiago, Chile, August.

(1990): Changing production patterns with social equity. The prime task of Latin American and Caribbean development in the 1990s, LC/G.1601-P, Santiago, Chile. United Nations publication, Sales No.: E.90.II.G.6.

(1995): La inversión extranjera en América Latina y el Caribe. Informe 1995, LC/G.1890, Santiago, Chile.

(1998): Foreign investment in Latin America and the Caribbean. 1997 Report, LC/G.1985-P, Santiago, Chile. United Nations publication, Sales No.: E.97.II.G.7.

(2000): Foreign investment in Latin America and the Caribbean. 1999 Report, LC/G.2061-P, Santiago, Chile. United Nations publication, Sales No.: E.00.II.G.4.

Fajnzylber, F. (1990): Industrialization in Latin America: From the "black box" to the "empty box": a comparison of contemporary industrialization patterns, Cuadernos de la CEPAL series, No. 60, LC/G.1534-P, Santiago, Chile, ECLAC. United Nations publication, Sales No.: E.89.II.G.5.
Ffrench-Davis, R., O. Muñoz and J.G. Palma (1998): The Latin American economies, 1950-1990, in L. Bethell (comp.), Latin America. Economy and society since 1930, Cambridge, Cambridge University Press.

Harberger, A. (1996): Latin America, in A.W. Coats, The post-1945 internationalization of economics. Annual supplement to volume 28. History of political economy, Durham, North Carolina, Duke University Press.

Hirschman, A. (1961): Ideologies of economic development in Latin America, in A. Hirschman (comp.), Latin American issues. Essays and comments, New York, Twentieth Century Fund.

Katz, J. (1998): Aprendizaje tecnológico ayer y hoy, Revista de la CEPAL, número extraordinario, LC/G.2037-P, Santiago, Chile, October.

Love, J.L. (1996a), Crafting the Third World. Theorizing underdevelopment in Rumania and Brazil, Stanford, Stanford University Press.

(1996b), Economic ideas and ideologies in Latin America since 1930, in L. Bethell, Ideas and ideologies in Latin America, Cambridge, Cambridge University Press.

(1996c), Las fuentes del estructuralismo latinoamericano, Desarrollo económico, vol. 36, No. 141, April-June.

Marinho, L.C. (1981): The transnational corporations and Latin America's present form of economic growth, CEPAL Review, No. 14, E/CEPaL/G.1179, Santiago, Chile, August.

Montecinos, V. (1997): Los economistas y las elites políticas en América Latina, Estudios internacionales, year 30, No. 119120, July-December.

Painter, D. (1999): The Cold War. An international history, London, Routledge.

Pinto, A. (1976): Styles of development in Latin America, CEPAL Review, No. 1, Santiago, Chile, first semester.

(1980): La internacionalización de la economía mundial. Una visión latinoamericana, Madrid, Ediciones de Cultura Hispánica.

Prebisch, R. (1950): The economic development of Latin America and its principal problems, E/CN.12/89, Lake Success, New York, United Nations. United Nations publication, Sales No.: 50.II.G.2.

(1963): Towards a dynamic development policy for Latin America, E/CN.12/680/Rev.1, New York, United Nations.

(1981): Capitalismo periférico. Crisis y transformación, Mexico City, Fondo de Cultura Económica.

Stumpo, G. (comp.) (1998): Empresas transnacionales. Procesos de reestructuración industrial y políticas económicas en América Latina, Buenos Aires, ECLAC/Alianza Editorial.

Sunkel, O. (1998): Desarrollo, subdesarrollo, dependencia, marginación y desigualdades espaciales: hacia un enfoque totalizante, in R. Bielschowsky, Cincuenta años de pensamiento en la CEPAL. Textos seleccionados, vol. 1, Santiago, Chile, ECLAC.

Williamson, J. (comp.) (1990): Latin American adjustment. How much has happened?, Washington, D.C., Institute for International Economics (IIE).

World Bank (1993): The East Asian miracle: Economic growth and public policy, Washington, D.C. 